\title{
Isolation and characterization of a haloalkane halidohydrolase from Rhodococcus erythropolis Y2
}

\author{
Paul J. Sallis, ${ }^{1}$ Susan J. Armfield,${ }^{2}$ Alan T. Bull ${ }^{1}$ and David J. Hardman ${ }^{1 *}$ \\ ${ }^{1}$ Biological Laboratory, University of Kent at Canterbury, Canterbury, Kent CT2 7NJ, UK \\ ${ }^{2}$ The Laboratory of the Government Chemist, Queens Road, Teddington, Middlesex TW11 OLY, UK
}

(Received 23 March 1989; revised 24 August 1989; accepted 4 October 1989)

\begin{abstract}
Rhodococcus erythropolis strain Y2, isolated from soil by enrichment culture using 1-chlorobutane, was able to utilize a range of halogenated aliphatic compounds as sole sources of carbon and energy. The ability to utilize 1chlorobutane was conferred by a single halidohydrolase-type haloalkane dehalogenase. The presence of the single enzyme in cell-free extracts was demonstrated by activity stain polyacrylamide gel electrophoresis. The purified enzyme was a monomeric protein with a relative molecular mass of $34 \mathrm{kDa}$ and demonstrated activity against a broad range of haloalkanes, haloalcohols and haloethers. The highest activity was found towards $\alpha, \omega$ disubstituted chloro- and bromo- $\mathrm{C}_{2}-\mathrm{C}_{6}$ alkanes and 4-chlorobutanol. The $K_{\mathrm{m}}$ value of the enzyme for 1-chlorobutane was $0.26 \mathrm{mM}$. A comparison of the $R$. erythropolis Y2 haloalkane halidohydrolase with other haloalkane dehalogenases is discussed on the basis of biochemical properties and $\mathrm{N}$-terminal amino acid sequence data.
\end{abstract}

\section{Introduction}

The large scale use of halogenated aliphatic compounds in industry and in agriculture has led to widespread contamination of the environment. Many such compounds have been designated as priority pollutants by the United States Environmental Protection Agency (Keith \& Teilliard, 1979) because of their recalcitrance, toxicity, carcinogenicity and potential teratogenicity.

The presence of halogen substituents often renders simple chemical structures recalcitrant (Alexander, 1965). Organisms possessing oxygenases, reductases or dehalogenases, which are capable of catalysing the cleavage of the carbon-halogen bonds, can mineralize haloalkanes and thereby utilize them as sources of carbon and energy (Hardman, 1990; unpublished data). Consequently, there has been considerable interest in the possibility of using such organisms and their enzymes for the detoxification of xenobiotic chemicals. In our experience, the halidohydrolase-type dehalogenases are of particular interest as they do not require cofactors and are relatively stable catalysts.

The halidohydrolases which have been extensively studied to date are the 2-haloacid dehalogenases (EC 3.8.1.2; Goldman et al., 1968) and the haloacetate dehalogenases (EC 3.8.1.3; Goldman, 1965). Microorganisms possessing these enzymes are readily isolated from most soils and many have been shown to produce more than one halidohydrolase with activity towards mono- and disubstituted 2-haloacids (Hardman \& Slater, 1981; Allison et al., 1983).

In contrast, there have been relatively few reports of the hydrolytic dehalogenation of haloalkanes and organisms containing haloalkane halidohydrolases are less readily isolated from the environment. Those haloalkane-degrading organisms which have been characterized usually possess a single enzyme active towards a broad range of haloalkanes and related compounds (Scholtz et al., 1987; Yokota et al., 1987; Janssen et al., 1988). However, Scholtz et al. (1988) provided evidence for the presence of three haloalkane dehalogenases in Arthrobacter sp. strain HAl.

We report here the isolation of a strain of Rhodococcus erythropolis, designated $\mathrm{Y} 2$, capable of growth on 1chlorobutane and a range of other $\alpha$-substituted chloroalkanes, and the characterization of the single haloalkane halidohydrolase produced by this organism.

\section{Methods}

Materials. Chemicals and reference proteins were purchased from Sigma except for 1-chlorododecane (Pfaltz Bauer) and all other halogenated substrates (Aldrich). DEAE-Sephacel and Sephadex G150 were purchased from Pharmacia-LKB; Biogel HT was from BioRad.

Isolation and maintenance of Rhodococcus erythropolis. The bacterium, subsequently identified and designated $R$. erythropolis $\mathrm{Y} 2$, was isolated 
by batch-enrichment culture. Soil samples were obtained from a discharge point at an industrial site where haloalkanes had been used for several decades. Soil samples $(5 \mathrm{~g})$ were incubated in $250 \mathrm{ml} \mathrm{screw}-$ top bottles containing $20 \mathrm{ml}$ defined growth medium (Slater et al., 1979) at $\mathrm{pH} 7.0$ containing modified quantities of $\left(1^{-1}\right): \mathrm{Na}_{2} \mathrm{HPO}_{4} .12 \mathrm{H}_{2} \mathrm{O}$, $4 \mathrm{~g} ; \mathrm{KH}_{2} \mathrm{PO}_{4}, 1 \mathrm{~g} ; \mathrm{NaHCO}_{3}, 1 \mathrm{~g}$; yeast extract, $20 \mathrm{mg} ; \mathrm{CoCl}_{2} .6 \mathrm{H}_{2} \mathrm{O}$, $100 \mu \mathrm{g} ; \mathrm{NiCl}_{2} .6 \mathrm{H}_{2} \mathrm{O}, 20 \mu \mathrm{g}$; and $\mathrm{H}_{3} \mathrm{BO}_{3}, 100 \mu \mathrm{g}$. 1-Chlorobutane was added as the sole carbon and energy source at $0.9 \mathrm{~g}^{-1}$. Enrichment cultures were incubated on a reciprocating shaker $(120$ r.p.m. $)$ at $30^{\circ} \mathrm{C}$ for $3 \mathrm{~d}$. Samples $(1 \mathrm{ml})$ from enrichment cultures were subcultured into the above medium $(100 \mathrm{ml})$ in $300 \mathrm{ml}$ screw-top bottles and incubated as above. After two further subcultures samples of the culture were serially diluted in order to produce separated colonies on nutrient agar. Inocula from all individual colonies were tested for their ability to grow in the above liquid medium with 1-chlorobutane as growth substrate. One isolate (Y2) was obtained which grew as an axenic culture.

Isolate $\mathrm{Y} 2$ was grown routinely in screw-top bottles containing less than $30 \%$ volume of defined growth medium and 1-chlorobutane at a final concentration of $0.7 \mathrm{~g} \mathrm{l}^{-1}$. Growth was monitored as $\mathrm{OD}_{600}$ and by $\mathrm{Cl}^{-}$release (Marius Chlor-O-Counter, FT Scientific Instruments, Tewkesbury, UK). Several terminally substituted chloroalkanes were tested for their ability to act as growth substrates under similar culture conditions.

Preparation of bacterial extracts. Bacteria were harvested by centrifugation at $9000 \mathrm{~g}$ for $10 \mathrm{~min}$, washed and resuspended in $100 \mathrm{~mm}$-glycine/ $\mathrm{NaOH}$ buffer, $\mathrm{pH} 9 \cdot 1$, then disrupted by five passages through a French pressure cell (SLM Instruments, Urbana, USA) at $138 \mathrm{MPa}$. Intact bacteria and debris were removed by centrifugation at $48000 \mathrm{~g}$ for $40 \mathrm{~min}$ to yield a cell-free extract which could be stored without further treatment for at least 3 months at $-20^{\circ} \mathrm{C}$ without detectable loss of dehalogenase activity.

Dehalogenase purification. The dehalogenase was purified from the cell-free extract using the three chromatographic steps described by Tsang et al. (1988) with the following modifications. (i) DEAESephacel. The column was equilibrated with $20 \mathrm{~mm}$-Tris/ $\mathrm{H}_{2} \mathrm{SO}_{4}$ buffer, pH 8.5 , and eluted with an $1800 \mathrm{ml}$ linear gradient of sodium sulphate $(0-400 \mathrm{~mm})$ in the same buffer. (ii) Hydroxyapatite. Active fractions from the previous step were diluted 1.5 -fold with $30 \mathrm{mM}$ glycine $/ \mathrm{NaOH}$ buffer, $\mathrm{pH} 9 \cdot 1$, before being applied to the column. The column was then eluted with a $600 \mathrm{ml}$ linear gradient $(0-100 \mathrm{mM})$ of sodium phosphate in $30 \mathrm{~mm}$-glycine/ $\mathrm{NaOH}$ buffer, $\mathrm{pH} 9 \cdot 1$. (iii) Gelfiltration. Active fractions from the previous step were concentrated by ultrafiltration (Amicon PM-10 membrane) to $5 \mathrm{ml}$, applied to a Sephadex G-150 column equilibrated with $100 \mathrm{~mm}$-glycine/ $\mathrm{NaOH}$ buffer, $\mathrm{pH} 9 \cdot 1$, and eluted with the same buffer. Active fractions were pooled, concentrated and stored at $-20{ }^{\circ} \mathrm{C}$ after addition of 1,4dithiothreitol $(100 \mu \mathrm{M})$.

Enzyme assay. Dehalogenase activity was measured in $10 \mathrm{ml}$ glassvials closed with Suba-seals in the following reaction mixture: $5 \mathrm{ml}$ $100 \mathrm{~mm}$-glycine/ $\mathrm{NaOH}$ buffer, $\mathrm{pH} 9 \cdot 1,4 \mu 1$ 1-chlorobutane (equivalent to $7.6 \mathrm{mM}$ ). After equilibration of the reaction mixture by shaking (120 r.p.m.) at $30^{\circ} \mathrm{C}$ for $15 \mathrm{~min}$, the assay was initiated by addition of the enzyme preparation $(5-200 \mu \mathrm{l})$. Samples $(1 \mathrm{ml})$ were withdrawn periodically and $\mathrm{Cl}^{-}$content determined by the method of Bergmann \& Sanik (1957)

During kinetic studies, enzyme-substrate reaction mixtures were shaken within a plugged $10 \mathrm{ml}$ syringe containing a $6 \mathrm{~mm}$ diameter glass-bead. By advancing the syringe piston during each sample withdrawal, the headspace volume was reduced to zero thus eliminating substrate losses through partition equilibrium.

The $\mathrm{pH}$ dependence of the haloalkane dehalogenase was determined in a reaction mixture containing $50 \mathrm{mM}$-Tris $/ 50 \mathrm{~mm}$-glycine $/ 50 \mathrm{~mm}$ - maleate adjusted to the required $\mathrm{pH}$ value by addition of $\mathrm{NaOH} / \mathrm{H}_{2} \mathrm{SO}_{4}$ before addition of substrate and enzyme.

An anaerobic assay was done by sparging $\mathrm{O}_{2}$-free nitrogen through a sample of $100 \mathrm{~mm}$-glycine/ $\mathrm{NaOH}$ buffer, $\mathrm{pH} 9 \cdot 1$, contained in a Subasealed glass-vial at $0^{\circ} \mathrm{C}$ for $2 \mathrm{~h}$ prior to the addition of substrate and enzyme. Incubation was at $30^{\circ} \mathrm{C}$.

One unit of dehalogenase activity (U) was defined as the amount of enzyme catalysing the release of $1 \mu \mathrm{mol} \mathrm{Cl}-\mathrm{min}^{-1}$.

1-Chlorobutane dehalogenation product determination. The dehalogenation product of 1-chlorobutane was determined by GLC. A megabore column $(25 \mathrm{~m} \times 0.530 \mathrm{~mm}, \mathrm{~J} \& \mathrm{~W}$ Scientific), with DB-Wax-bonded liquid phase, was used with helium as carrier gas. The column temperature was $50^{\circ} \mathrm{C}$ and detection was by flame ionization. The product identity was confirmed by reference to chromatograms of a number of $\mathrm{C}_{4}$ standards.

Protein determination. Protein was measured by the method of Bradford (1976) using BSA as the standard.

$P A G E$. Dehalogenase activity was visualized after native PAGE by an activity reaction in the gel (cf. Hardman \& Slater, 1981). Haloalkane substrates were incorporated into the gel as an emulsion by sonication of $10-200 \mu \mathrm{l}$ haloalkane with $40 \mathrm{ml}$ acrylamide solution immediately before casting the gel. Dehalogenase activity bands were visualized after electrophoresis $\left(4^{\circ} \mathrm{C}\right)$ as regions of clearing in the emulsion after incubation at $37^{\circ} \mathrm{C}$ for $20-90 \mathrm{~min}$, depending on the number of enzyme units loaded onto the gel.

Isoelectric point determination. The isoelectric point $(\mathrm{pI})$ of the purified dehalogenase was determined using Ampholine PAG plates (LKB), by reference to protein standards according to the manufacturer's recommendations.

Determination of molecular mass. The molecular mass of the purified denatured dehalogenase was determined by SDS-PAGE using $7-20 \%$ polyacrylamide gradient gels (Tsang et al., 1988). Molecular mass standards were MW-SDS-70L molecular mass markers (Sigma): BSA, $66 \mathrm{kDa}$; chick egg albumin, $45 \mathrm{kDa}$; rabbit glyceraldehyde-3-phosphate dehydrogenase, $36 \mathrm{kDa}$; bovine carbonic anhydrase, $29 \mathrm{kDa}$; bovine trypsinogen, $24 \mathrm{kDa}$; soybean trypsin inhibitor, $20 \cdot 1 \mathrm{kDa}$, bovine milk $\alpha$-lactalbumin, $14 \cdot 2 \mathrm{kDa}$. Gels were stained with Coomassie blue G-250.

The native molecular mass was determined by gel-filtration chromatography using a Sephadex G-150 column $(2.6 \times 100 \mathrm{~cm})$ equilibrated with $200 \mathrm{~mm}$-Tris/ $\mathrm{H}_{2} \mathrm{SO}_{4}$ buffer, $\mathrm{pH} 8 \cdot 0$. The dehalogenase preparation $(5 \mathrm{ml})$ was applied to the column and eluted with the same buffer (flow rate $0 \cdot 2 \mathrm{ml} \mathrm{min}^{-1}$ ). The column was calibrated with blue dextran, $2000 \mathrm{kDa}$; BSA, $66 \mathrm{kDa}$; chicken egg albumin, $45 \mathrm{kDa}$; bovine carbonic anhydrase, $29 \mathrm{kDa}$; and horse heart cytochrome $c$, $12 \mathrm{kDa}$.

$N$-Terminal amino acid sequence. The purified enzyme was dialysed against $20 \mathrm{~mm}-\mathrm{KH}_{2} \mathrm{PO}_{4} / \mathrm{NaOH}$ buffer, $\mathrm{pH} 7 \cdot 5$, and concentrated to $1 \mathrm{mg} \mathrm{ml} \mathrm{m}^{-1}$ by ultrafiltration (Amicon PM-10 membrane) before lyophilization. The $\mathrm{N}$-terminal amino acid sequence was determined using automated Edman degradation/HPLC analysis with an automatic protein sequencer (model 8710; JayTee Biosciences, Herne Bay, Kent, UK).

\section{Results}

\section{Characterization of the bacterial isolate}

Bacterial isolate Y2, capable of utilizing 1-chlorobutane as its sole source of carbon and energy, was isolated by 
batch-enrichment from a soil sample which had previously been exposed to haloalkanes. This isolate was identified by the National Collection of Industrial and Marine Bacteria (Torry Research Station, Aberdeen, $\mathrm{UK}$ ) as Rhodococcus erythropolis. The genus was determined as a result of chemotaxonomic analysis based on the fatty acid profile and the presence of mycolic acids (Goodfellow, 1986). However, the strain was atypical in utilizing benzoate and tyrosine as growth substrates. In addition to growth on 1-chlorobutane, $R$. erythropolis $\mathrm{Y} 2$ could utilize the following $\alpha$-substituted chloroalkanes: 1-chloropropane, 1-chloropentane, 1-chlorohexane, 1chlorododecane, 1-chlorotetradecane, 1-chlorohexadecane and 1-chlorooctadecane.

The dehalogenase of $R$. erythropolis Y2 was inducible and active towards a considerably greater range of halogenated aliphatic compounds than would support growth of the organism. The enzyme catalysed the cleavage of a number of mono- and disubstituted chloroand bromoalkanes with carbon chain lengths from $\mathrm{C}_{1}$ to $\mathrm{C}_{16}$ (Table 1). The enzyme had greater activity towards terminally ( $\alpha$ and $\omega$ ) substituted substrates than towards those with mid-chain substituents.

Table 1. Relative activity of the crude haloalkane halidohydrolase of R. erythropolis $Y 2$ towards halogenated aliphatic substrates

Enzyme assays contained $5 \mathrm{ml} 100 \mathrm{~mm}$-glycine/ $\mathrm{NaOH}$ buffer, $\mathrm{pH} 9 \cdot 1,50 \mu \mathrm{l}$ of cell-free extract, and $4 \mu \mathrm{l}$ of one of the substrates (or $40 \mu \mathrm{l}$ of a $10 \%, w / v$, neutral solution of the substrate for the haloacids). Relative activities were determined by comparison with the activity towards 1-chlorobutane $[0.012 \mathrm{U} \text { (mg protein })^{-1}$ standardized to 100$]$.

\begin{tabular}{lrlr}
\hline \hline \multicolumn{1}{c}{ Substrate } & $\begin{array}{c}\text { Relative } \\
\text { activity }\end{array}$ & \multicolumn{1}{c}{ Substrate } & $\begin{array}{r}\text { Relative } \\
\text { activity }\end{array}$ \\
\hline 1-Chloropropane & 8 & 2-Chlorobutane & 3 \\
1-Chlorobutane & 100 & 2-Bromobutane & 67 \\
1-Bromobutane & 100 & 1,2-Dichlorobutane & 4 \\
1-Chloropentane & 132 & 1,2-Dibromopropane & 132 \\
1-Chlorohexane & 107 & Chloroacetate & 0 \\
1-Bromohexane & 66 & 2-Chloropropionate & 0 \\
1-Chloroheptane & 104 & 2-Chloroethanol & 15 \\
1-Chlorooctane & 72 & 3-Chloropropan-1-ol & 18 \\
1-Chlorononane & 85 & 4-Chlorobutan-1-ol & 121 \\
1-Chlorododecane & 53 & bis(2-Chloroethyl)ether & 60 \\
1-Chlorotetradecane & 10 & & \\
1-Chlorohexadecane & 8 & & \\
1-Chlorooctadecane & 0 & & \\
Dichloromethane & 0 & & \\
Dibromomethane & 3 & & \\
1,2-Dichloroethane & 6 & & \\
1,2-Dibromoethane & 802 & & \\
1,3-Dichloropropane & 202 & & \\
1,4-Dichlorobutane & 232 & & \\
1,6-Dichlorohexane & 168 & & \\
1,9-Dichlorononane & 61 & & \\
1,10-Dichlorodecane & 61 & & \\
\hline \hline
\end{tabular}

Although there was no difference between the dehalogenation rates of 1-chloro- and 1-bromobutane, there was a marked difference in the activity of the enzyme against 2-chloro- and 2-bromobutane. Similarly, 1,2-dibromoethane was degraded more rapidly (more than 100-fold) than 1,2-dichloroethane.

Several other halocompounds were dehalogenated by the $R$. erythropolis Y2 dehalogenase, including alcohols and an ether with terminal chloro-substituents (Table 1). However, 2-chloropropionic acid and chloroacetic acid were not substrates for the enzyme.

\section{Polyacrylamide gel electrophoretic studies of the dehalogenase}

Native PAGE run with gels containing emulsions of different haloalkanes showed the same single clearance band with an $R_{F}$ of 0.76 in each substrate emulsion (Fig. 1). Slight darkening of the gel at $R_{F} 1.00$ was due to marker dye colouration and not to substrate clearing. Streaking of the substrate gel above the activity band was the result of enzyme activity occurring at $4{ }^{\circ} \mathrm{C}$ during electrophoresis. Variation in the solubility of the different haloalkane substrates meant that the degree of emulsion clearance in the gels was not proportional to the relative activities of the enzyme towards each substrate (Table 1).

\section{Enzyme purification}

The enzyme purification protocol produced a single dehalogenase activity peak at each chromatographic step, thus confirming the native PAGE analysis. Specific enzyme activity was increased 21 -fold during purification (Table 2), which gave a final preparation containing one major protein band on SDS-PAGE (Fig. 2). Although the protein was not completely homogeneous in the Sephadex G-150 effluent, indicated by minor bands at high sample loading (Fig. 2), the major band stained by Coomassie blue R250 (Fig. 2) was identified as the dehalogenase by SDS-PAGE of gel slices taken from the clearing zones in native gels.

Table 2. Purification of the haloalkane halidohydrolase of $R$. erythropolis $Y 2$

\begin{tabular}{lrcccc}
\hline \hline \multicolumn{1}{c}{ Step } & $\begin{array}{r}\text { Vol. } \\
(\mathrm{ml})\end{array}$ & $\begin{array}{c}\text { Protein } \\
\left(\mathrm{mg} \mathrm{ml}^{-1}\right)\end{array}$ & $\begin{array}{c}\text { Specific } \\
\text { activity } \\
\left(\mathrm{U} \mathrm{mg}^{-1}\right)\end{array}$ & $\begin{array}{c}\text { Recovery } \\
(\%)\end{array}$ & $\begin{array}{c}\text { Purification } \\
(- \text {-fold })\end{array}$ \\
\hline Cell-free-extract & 47.0 & $9 \cdot 7$ & 0.016 & 100 & - \\
DEAE-Sephacel & $270 \cdot 0$ & 0.2 & 0.11 & 81 & 6.9 \\
Biogel HT & $3 \cdot 2$ & $3 \cdot 5$ & 0.14 & 21 & 8.8 \\
Sephadex G-150 & 1.5 & $2 \cdot 1$ & 0.33 & 14 & 21.0 \\
\hline \hline
\end{tabular}




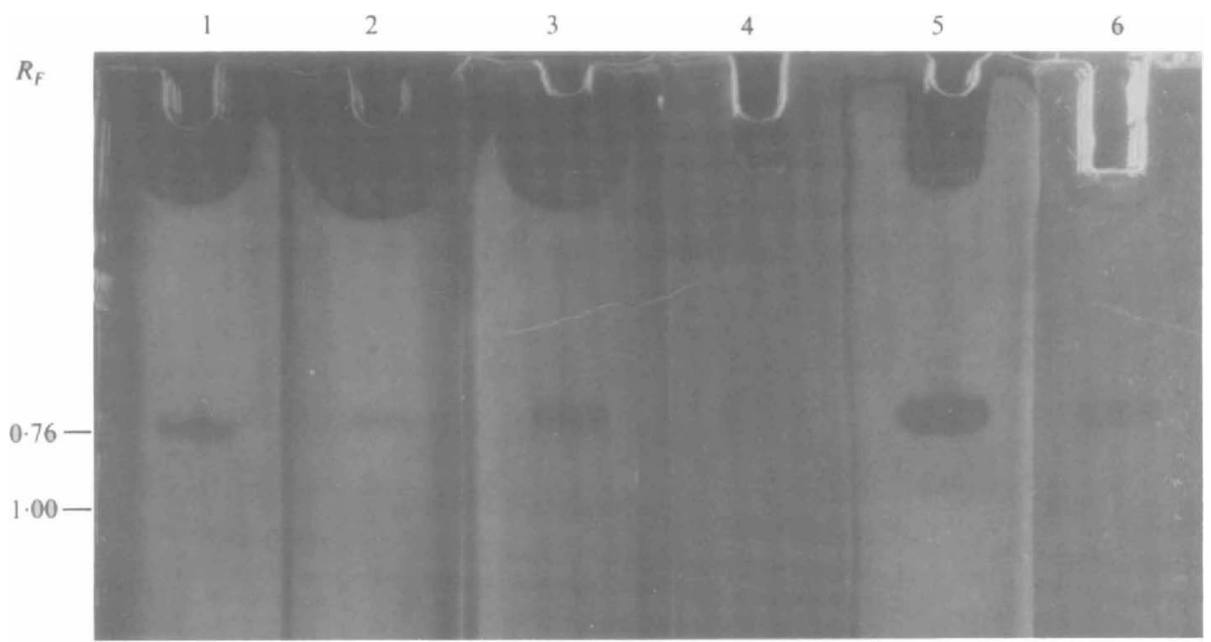

Fig. 1. Native PAGE of $R$. erythropolis Y2 cell-free extract. Substrate emulsions in tracks 1 to 6 were; 1,2-dibromopropane, 1,2dibromoethane, 2-bromobutane, 1,9-dichlorononane, 1,6-dichlorohexane and l-chlorobutane, respectively. Each track was loaded with $250 \mu \mathrm{g}$ protein.

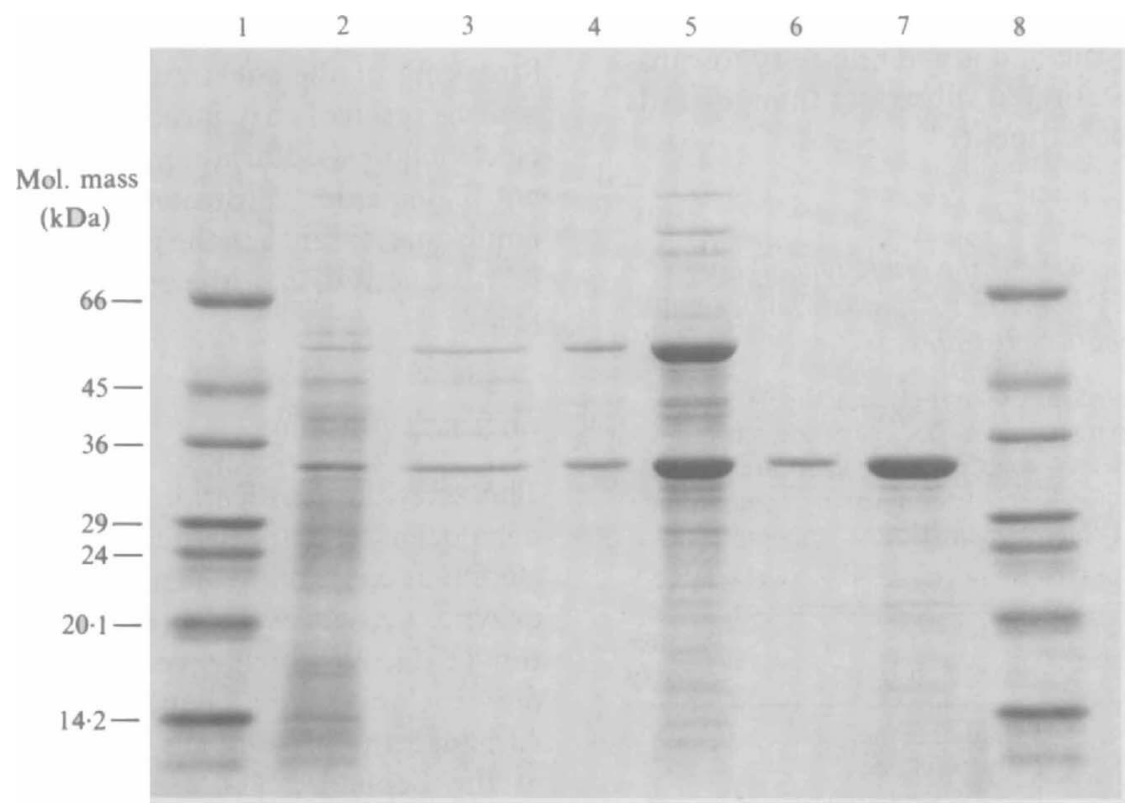

Fig. 2. Gradient SDS-PAGE of $R$. erythropolis Y2 halidohydrolase at different stages of enzyme purification. Tracks 1 and 8 , SDS-7 marker proteins $(7 \times 10 \mu \mathrm{g}$ protein); 2 , cell-free extract $(200 \mu \mathrm{g}$ protein); 3, DEAE-Sephacel effluent $(30 \mu \mathrm{g}$ protein); 4 , Biogel HT effluent ( $30 \mu \mathrm{g}$ protein); 5 , Biogel HT effluent concentrate ( $200 \mu \mathrm{g}$ protein); 6 , Sephadex G-150 effluent (10 $\mu \mathrm{g}$ protein); 7 , Sephadex G-150 effluent concentrate ( $80 \mu \mathrm{g}$ protein).

\section{Characterization of the purified enzyme}

The haloalkane dehalogenating activity of $R$. erythropolis Y2 was the result of a single broad-specificity enzyme which was equally active under aerobic and anaerobic assay conditions. The product of its activity towards 1chlorobutane was identified as n-butanol by GLC, indicating that the enzyme catalysed a hydrolytic dehalogenation.

The dehalogenase had optimum activity at $\mathrm{pH} 9 \cdot 2$ but retained more than $50 \%$ of its maximum activity over the range $\mathrm{pH} 7 \cdot 5-11 \cdot 0$. Activity was very low at $\mathrm{pH} 5-6$. The isoelectric point of the enzyme was estimated to be $4 \cdot 7$.

Dehalogenase activity increased with assay temperature up to $37^{\circ} \mathrm{C}$. Above this temperature enzyme activity declined as thermal inactivation became significant. From an Arrhenius plot of the temperature/activity data an enzyme activation energy of $43 \mathrm{~kJ} \mathrm{~mol}^{-1}$ was estimated.

The effect of 1-chlorobutane concentration on the 
Table 3. Effect of inhibitors on haloalkane halidohydrolase activity from $R$. erythropolis $Y 2$

Enzyme assays contained $5 \mathrm{ml} 100 \mathrm{~mm}$-glycine $/ \mathrm{NaOH}$ buffer, pH 9.1, which had been made $1 \mathrm{mM}$ with respect to each of the inhibitors, $4 \mu \mathrm{l}$ 1-chlorobutane and $50 \mu \mathrm{l}$ of a solution of purified enzyme. The amount of inhibition was determined by reference to a control assay containing no inhibitor. The specific activity of the control assay was $0.30 \mathrm{U}$ (mg protein) ${ }^{-1}$

\begin{tabular}{lrlr}
\hline Inhibitor & $\begin{array}{c}\text { Inhibition } \\
(\%)\end{array}$ & \multicolumn{1}{c}{ Inhibitor } & $\begin{array}{c}\text { Inhibition } \\
(\%)\end{array}$ \\
\hline $\mathrm{CaCl}_{2}$ & 46 & N-Ethylmaleimide & 69 \\
$\mathrm{CuSO}_{4}$ & 100 & Dibromomethane & 48 \\
$\mathrm{FeSO}_{4}$ & 83 & Dichloromethane & 23 \\
$\mathrm{NiSO}_{4}$ & 93 & Dichloroacetate & 0 \\
$\mathrm{ZnSO}_{4}$ & 89 & EDTA & 0 \\
$\mathrm{HgCl}_{2}$ & 100 & & \\
$\mathrm{~K}_{2} \mathrm{SO}_{4}$ & 0 & & \\
$\mathrm{KCl}$ & 0 & & \\
\hline
\end{tabular}

dehalogenase activity was determined over the range 0.2-1.0 mM. The Eadie-Hofstee transformation of the data produced an apparent $K_{\mathrm{m}}$ of $0.26 \mathrm{~mm}$ and a value for $V$ of $0.38 \mu \mathrm{mol} \mathrm{Cl}^{-} \mathrm{min}^{-1}$ (mg protein) $)^{-1}$.

The effect of inhibitors on the hydrolysis of 1chlorobutane is shown in Table 3. Thiol reagents $\left(\mathrm{Hg}^{2+}\right.$, $\mathrm{N}$-ethylmaleimide) were effective inhibitors as were a number of other divalent metal ions (e.g. $\mathrm{Cu}^{2+}, \mathrm{Zn}^{2+}$ ) in comparison with the monovalent metal ion $\mathrm{K}^{+}$. Halocompounds which were poor substrates for the enzyme (i.e. dichloro- and dibromomethane; Table 2) were effective inhibitors of 1-chlorobutane dehalogenation although the type of inhibition was not investigated. However, the non-substrate halocompound dichloroacetate did not act as an inhibitor.

The molecular mass of the enzyme was estimated to be $36 \mathrm{kDa}$ by gel-filtration and $34 \mathrm{kDa}$ by SDS-PAGE (Fig. 2 ); it was therefore considered to be a monomeric protein.

The N-terminal amino acid sequence for the first 20 residues of the purified enzyme was: Ser-Glu-Ile-GlyThr-Gly-Phe-Pro-Phe-Asp-Pro-His-Tyr-Val-Glu-ValLeu-Gly-Glu-Arg.

\section{Discussion}

The range of haloalkane growth substrates utilized by $R$. erythropolis $\mathrm{Y} 2\left(\mathrm{C}_{3}-\mathrm{C}_{16}\right)$ is considerably greater than that reported for most other haloalkane-utilizing bacteria, with the exception of Arthrobacter sp. strain $\mathrm{HAl}$ which is able to utilize halosubstituted $\mathrm{C}_{2}-\mathrm{C}_{16}$ alkanes (Scholtz et al., 1988). Janssen et al (1987) described a bacterial isolate, GJ70, capable of growth on terminally substituted $\mathrm{C}_{2}-\mathrm{C}_{9}$ alkanes whilst Yokota et al. (1986) reported growth of two bacterial isolates on agar containing 1,10-dichlorodecane. Xanthobacter autotrophicus GJ10 (Janssen et al., 1985) had a considerably more restricted substrate profile, being capable of growth only on mono- and disubstituted $C_{2}$ and $C_{3}$ compounds.

The observation that cell-free extracts of $R$. erythropolis $\mathrm{Y} 2$ catalysed an oxygen-independent dehalogenation of 1-chlorobutane and that the product of the reaction was n-butanol suggests that the enzyme catalyses a hydrolytic dehalogenation, and so can be classified as a halidohydrolase.

Activity stain PAGE, utilizing $\mathrm{Ag}^{+}$to precipitate free halide ions in regions of dehalogenase activities, has been employed to identify electrophoretically distinguishable 2-haloacid halidohydrolases (Slater et al., 1979; Hardman \& Slater, 1981; Allison et al., 1983). The same technique was used by Scholtz et al. (1988) to visualize one of the dehalogenase activities in Arthrobacter sp. HAl. In this paper we describe a more direct visualization procedure which utilizes the greater solubility of the reaction product of enzymic dehalogenation so that regions of dehalogenase activity are identified as zones of clearance in the substrate emulsion contained in the gel (see Fig. 1). Using this technique, a single halidohydrolase was identified in cell-free extracts of $R$. erythropolis $\mathrm{Y} 2$, and was subsequently purified.

The halidohydrolase of $R$. erythropolis $\mathrm{Y} 2$ possesses one of the broadest substrate ranges reported to date (cf. Scholtz et al., 1987; Yokota et al., 1987; Janssen et al., 1988). This halidohydrolase showed little or no activity towards terminally halogenated $\mathrm{C}_{14}, \mathrm{C}_{16}$ and $\mathrm{C}_{18}$ alkanes, but the organism could utilize these haloalkanes as substrates for growth. This observation suggests that a second enzyme may be present, which is either active in the dehalogenation of these longer-chain haloalkanes or in their modification to short-chain halocompounds.

The biochemical characteristics of the $R$. erythropolis Y2 halidohydrolase closely resembled those of enzymes from Corynebacterium sp. m-15-3 (data from Yokota $e t$ al., 1987) and Arthrobacter sp. HAl (data from Scholtz et al., 1987). The three enzymes have similar $\mathrm{pH}$ optima, ranging from $\mathrm{pH} 9 \cdot 2-9 \cdot 5$, and are monomeric proteins with a molecular mass of $34-36 \mathrm{kDa}$. The isoelectric point for the $R$. erythropolis Y2 enzyme (4.7) is similar to that for the Corynebacterium sp. m-15-3 enzyme (4.5). Additionally, the activation energy of the Arthrobacter sp. $\mathrm{HAl}$ dehalogenase $\left(40 \mathrm{~kJ} \mathrm{~mol}^{-1}\right)$ is very similar to that of the $R$. erythropolis $\mathrm{Y} 2$ halidohydrolase $\left(42.9 \mathrm{~kJ} \mathrm{~mol}^{-1}\right)$. The other haloalkane dehalogenases reported to date - in Xanthobacter autotrophicus GJ10 (Keuning et al., 1985) and strain GJ70 (Janssen et al., 1988) - have fewer apparent similaries, with more acidic pH optima and higher activation energies (55- 
$59 \mathrm{~kJ} \mathrm{~mol}^{-1}$ ), while the dehalogenase of GJ70 had a notably lower molecular mass $(28 \mathrm{kDa})$.

The $K_{\mathrm{m}}$ values of the dehalogenases from $X$. autotrophicus strain GJ70, Corynebacterium sp. m-15-3, Arthrobacter $\mathrm{sp}$. $\mathrm{HAl}$ and $R$. erythropolis $\mathrm{Y} 2$ for 1-chlorobutane all fall in the range $0.06-0.40 \mathrm{~mm}$. However, the $V$ value for the $R$. erythropolis $\mathrm{Y} 2$ halidohydrolase is considerably lower $\left[0.382 \mu \mathrm{mol} \mathrm{min}^{-1}(\mathrm{mg} \text { protein })^{-1}\right]$ than those for the other enzymes [approximately $1.5 \mu \mathrm{mol} \mathrm{min}^{-1}(\mathrm{mg}$ protein $)^{-1}$.

The most notable similarity between the R. erythropolis enzyme and that of Arthrobacter sp. $\mathrm{HAl}$ is the $100 \%$ homology between their $\mathrm{N}$-terminal amino acid sequences; at least 17 of the first 18 amino acid residues are identical. (Arthrobacter sequence data from Scholtz et al., 1987.) This is in contrast to major differences between the N-terminal sequences of these two enzymes and that of the $X$. autotrophicus GJ10 enzyme (Keuning et al., 1985), and the Hyphomicrobium sp. DM2 enzyme (Kohler-Staub et al., 1986). The degree of $\mathrm{N}$-terminal homology between the $R$. erythropolis Y2 and Arthrobacter $\mathrm{sp}$. HAl halidohydrolases raises interesting questions about the evolution of these enzymes. These actinomycetes were isolated from geographically separate industrial sites. The presence of biogenic haloalkanes in the environment might suggest that haloalkane dehalogenases have not evolved recently, thus the possibility of parallel evolution from a common ancestral protein or the spread of dehalogenase gene(s) or plasmids is a plausible explanation of this homology. R. erythropolis Y2 has been shown to harbour at least one plasmid (C. Fletcher, V. Vienravi, A. T. Bull \& D. J. Hardman unpublished data). The evolution of dehalogenase activities from ancestral hydrolases has been proposed as a mechanism by which the multiple forms of the 2haloacid dehalogenases arose (Tsang et al., 1988) and this hypothesis is being tested further in the system reported in this paper.

We thank Miss Clare Fletcher for excellent technical assistance, the Department of Trade and Industry for its support through the Laboratory of the Government Chemist/University of Kent BIOTRANS project and JayTee Biosciences for the use of their model 8710 automatic protein sequencer.

\section{References}

AleXander, M. (1965). Biodegradation: problems of molecular recalcitrance and microbial fallibility. Advances in Applied Microbiology $7,35-76$.
Allison, N., Skinner, A. J. \& Cooper, R. A. (1983). The dehalogenase of a 2,2-dichloropropionate-degrading bacterium. Journal of General Microbiology 129, 1283-1293.

BergmanN, J. G. \& SaniK, J. (1957). Determination of trace amounts of chlorine in naphtha. Analytical Biochemistry 29, 241-243.

BRADFORD, M. M. (1976). A rapid and sensitive method for the quantitation of microgram quantities of protein utilizing the principle of protein-dye binding. Analytical Biochemistry 72, 248-254.

Goldman, P. (1965). The enzymatic cleavage of C-F bond in fluoroacetate. Journal of Biological Chemistry 240, 3434-3438.

Goldman, P., Milne, G. W. A. \& Keister, D. B. (1968). Carbonhalogen bond cleavage. III. Studies on bacterial halidohydrolases. Journal of Biological Chemistry 243, 428-434.

GoOdFELlow, M. (1986). Genus Rhodococcus. In Bergey's Manual of Systematic Bacteriology, vol. 2, pp. 1472-1481. Edited by P. H. A. Sneath. Baltimore: Williams \& Wilkins.

HARDMAN, D. J. (1990). Biotransformation of halogenated compounds: enzymatic cleavage of carbon halogen bonds. Critical Reviews in Biotechnology (in the Press).

HARDMAN, D. J. \& Slater, J. H. (1981). Dehalogenases in soil bacteria. Journal of General Microbiology 123, 117-128.

JANSSEN, D. B., Scheper, A., Dijkhuizen, L. \& Witholt, B. (1985) Degradation of halogenated aliphatic compounds by Xanthobacter autotrophicus GJ10. Applied and Environmental Microbiology 49, 673-677.

JANSSEN, D. B., JAGER, D. \& Witholt, B. (1987). Degradation of $\mathrm{n}$-haloalkanes and $\alpha, \omega$-dihaloalkanes by wild-type and mutants of Acinetobacter sp. strain GJ70. Applied and Environmental Microbiology 53, 561-566.

Janssen, D. B., Gerritse, J., Brackman, J., KalK, C., JaGer, D. \& WITHOLT, B. (1988). Purification and characterization of a bacterial dehalogenase with activity toward halogenated alkanes, alcohols and ethers. European Journal of Biochemistry 171, 67-72.

Keith, L. H. \& Teilliard, W. A. (1979). Priority pollutants I: a perspective view. Environmental Science and Technology 13, 416-423.

Keuning, S., Janssen, D. B. \& Witholt, B. (1985). Purification and characterization of hydrolytic haloalkane dehalogenase from Xanthobacter autotrophicus GJ10. Journal of Bacteriology 163, 635-639.

Kohler-Staub, D., Hartmans, S., Galli, R., Suter, F. \& Leisinger, T. (1986). Evidence for identical dichloromethane dehalogenases in different methylotrophic bacteria. Journal of General Microbiology 132, 2837-2843.

SChOlTZ, R., LeIsinger, T., SUter, F. \& CoOK, A. M. (1987) Characterization of 1-chlorohexane halidohydrolase, a dehalogenase of wide substrate range from an Arthrobacter sp. Journal of Bacteriology 169, 5015-5021.

Scholtz, R., Messi, F., Leisinger, T. \& CoOK, A. M. (1988). Three dehalogenases and physiological restraints in the biodegradation of haloalkanes by Arthrobacter sp. strain HA1. Applied and Environmental Microbiology 54, 3034-3038.

Slater, J. H., lovatt, D., Weightman, A. J., Senior, E. \& Bull, A. T. (1979). The growth of Pseudomonas putida on chlorinated aliphatic acids and its dehalogenase activity. Journal of General Microbiology 114, 125-136.

Tsang, J. S. H., Sallis, P. J., Bull, A. T. \& Hardman, D. J. (1988). A monobromoacetate dehalogenase from Pseudomonas cepacia MBA4. Archives of Microbiology 150, 441-446.

Yokota, T., FusE, H., OMORI, T. \& Minoda, Y. (1986). Microbial dehalogenation of haloalkanes mediated by oxygenase or halidohydrolase. Agricultural and Biological Chemistry 50, 453-460.

Yokota, T., OMORI, T. \& Kodama, T. (1987). Purification and properties of haloalkane dehalogenase from Corynebacterium sp. m-15-3. Journal of Bacteriology 169, 4049-4054. 